\title{
Mobile Commerce and Consumers' Online Purchase Orientation in Poland, Croatia and Serbia
}

\author{
Magdalena Stefańska \\ Poznan University of Economics and Business, Faculty of Management, \\ Poland \\ Blazenka Knezevic \\ University of Zagreb, Faculty of Economics and Business Zagreb, Croatia \\ Dragan Stojkovic \\ University of Belgrade, Faculty of Economics, Serbia
}

\section{Abstract}

As an innovative approach to retail, mobile commerce develops rapidly during last decade. It brings new challenges and opportunities in front of retailers who have to adapt their business strategies to new generation shoppers. With a good understanding of the shoppers' online purchase intention, retailers are able to develop effective online strategies to attract new and keep loyal web-shopping customers. The purpose of this paper is to explain the online shopping orientation in the context of country of origin. There is a limited number of such research in Central and Eastern Europe, so there is a lack of knowledge about young consumers from this region and their attitude as mobile technology users. The article is based on the research conducted in Poland, Croatia and Serbia where 454 young non randomly selected respondents answered online survey questions. The research hypotheses were tested using correlation and non-parametric statistics. Differences between observed countries suggest that there is a necessity to adapt approach concerning online retailing even at the market with similar characteristics. Therefore, creators of marketing and sales strategies of online and omnichannel companies should consider this fact when planning business strategies.

Keywords: mobile commerce, online purchase orientation, retail innovation, smartphone shoppers, omnichannel retailing

JEL classification: L81, L86, M31

\section{Introduction}

The development of online marketing strategy became crucial to contemporary retailers due to the fact, that generations $Y$ and $Z$ are strongly oriented on online shopping. Data from many countries show that e-commerce and m-commerce is rapidly growing with much higher dynamics than traditional offline sales. To explain the change in consumer behaviour, researchers concentrate on the model group of TAM -technology adaptation models (Venkatesh et al., 2003; Kim, 2012), world of mouth influence (Hennig-Thurau et al., 2003; Cheung et al., 2009) perceived benefits and motives (Forsythe et al., 2006; Sarkar, 2011; Childers et al., 2001; Cha, 2011), but also on trust and perceived risk connected with online shopping (Pavlou, 2003; Lee et al., 2001; McKnight, 2001; Suh et al., 2003, Brockett et al., 2012). 
In previous research (Knezevic et al., 2017) we observed very similar attitude of young customers from different countries when analysing generally using mobile devices and mobile applications by generation of Millennials. But we suppose that perceptions and motivations towards mobile applications may differentiate between countries. In fact, country as dimension is not often explored in the context of consumers' online behaviour even though some papers discuss the differences of online business according to country (Durbhakula et al., 2011).

Poland, Croatia and Serbia have been chosen to be compared in this paper. This is due to a number of similarities these countries have, primarily their socialist heritage and alike macroeconomic and wider socio-economic trends. Also, certain differences between these countries, such as their position with regard to European Union membership status and resulting experiences, further contribute to their suitableness as a geographical area to be covered.

The structure of the paper is as follows. Firstly, we explain the level of adoption of online services in selected countries, then we give a theoretical framework of mobile commerce from the aspect of motives and benefits connected with online purchase. Finally, on the basis of primary research results we explore correlation between online shopping orientation and motives and benefits of using mobile applications and test differences in online purchase orientation among countries.

\section{Level of adoption of Internet and smart mobile phones technologies in Poland, Croatia and Serbia}

In Table 1 data of Internet, social networks (Facebook) and smartphones penetration rates are shown for Croatia, Poland and Serbia. In all observed countries, penetration rates are above $50 \%$ for Internet and smartphones, but for social networks, countries differ to some extent. As shown in Table 1, in Croatia $42,6 \%$ of population uses Facebook, in Poland $36,8 \%$ and in Serbia 50,6\%. Compared to average values given by Eurostat (2017a and 2017b) and Internet World Statistics (2017), for all three countries Internet penetration rates are significantly above world averages, but when we make comparison with European or EU averages the situation is different. Croatian Internet penetration rate $(75 \%)$ is in line with the European average $(73,5 \%)$, but below EU-28 average $(79,3 \%)$ while Poland and Serbia have penetration rates below European averages. However, over the time we can observe a significant growth of smartphone usage statistics in last couple years and predictions are that they are going to grow above 60\% till 2021 (Statista 2016).

The conditions and process of growth $\mathrm{m}$-commerce depends on many factors. As Gehrt et al. (2007) noticed, shopping online research enhanced our understanding of the nature of online shopping orientations in different countries. Smartphones are present in student population in Croatia, Poland and Serbia. According to Knezevic et al. (2017), over $95 \%$ of students have smartphone and more than three quarter has been using it over 2 years. However, same study (Knezevic et al., 2017) claims that students in Croatia are much more willing to buy goods and services using smartphones than their counterparts in Poland and Serbia. The research confirmed Turban's claim that contemporary young consumers are so-called "handset generation" (Turban et al., 2012, p. 279). In all three countries, the customers are very experienced and heavily smartphone-oriented users. It has strong managerial implications - retailers and generally marketers should pay more attention on communication through mobile devices, especially in creating more personalized messages and sales promotion offers. 
Table 1

Internet, Facebook and Smartphone Usage in Total Population

\begin{tabular}{llll}
\hline Country & Internet users & Facebook users & Smartphone users \\
& $\mathbf{2 0 1 5}$ & $\mathbf{2 0 1 5}$ & $\mathbf{2 0 1 5}$ \\
\hline Croatia & $75,0 \%$ & $42,6 \%$ & $61,0 \%$ \\
Poland & $67,5 \%$ & $36,8 \%$ & $59,0 \%$ \\
Serbia & $66,2 \%$ & $50,6 \%$ & $50,0 \%$ \\
\hline
\end{tabular}

Source: Authors' work according to Internet World Statistics (2017) and Statista (2016)

\section{Mobile Commerce benefits - a theoretical insight}

Therefore, some authors such as Yuan et al. (2004) and Zhang et al. (2012) emphasize that $\mathrm{M}$-commerce is the logical extension and a new wave of $\mathrm{e}$ commerce future development. Turban et al. (2015, p. 262) describe 4 key valueadded attributes of m-commerce: (1) ubiquity, (2) convenience, (3) interactivity and (4) personalization. This is in line to benefits from the consumer point of view given by Chaffey (2007, p. 133). According to Chaffey (2007), ubiquity refers to accessibility of information from any location in a real time, while convenience refers to ease of use of mobile devices in comparison to desktop devices, which are smaller and thus more usable for information access on the move. Mobile devices improve interactivity because users are able to communicate, search for information and use services in a real time. Moreover, the individual usage of mobile devices enables a high level of personalization according needs and requests of an individual user, which gives a business opportunity for delivering personalized information, products and services. The knowledge on users' physical locations in a real time creates a business opportunity to offer fully personalized location-based information, services and products (see Turban et al., p. 280-285).

Kabir et al. (2011) highlighted the major m-commerce success factors that company should pay attention when developing $\mathrm{m}$-commerce strategy, as follows: System Quality (online response time, 24-hour availability, page loading speed, visual appearance), Content Quality (understandability, timeliness, and preciseness), Trust, Support (trucking order status, account maintenance, payment alternatives, Frequently Asked Question), Mobility and Personalization.

The problem of shopping motivation and the idea of segmenting online shoppers was a subject of a study Rohm et al. (2004). The research by Stefanska et al. (2017) conducted in Poland among Polish and foreign students revealed that the most frequently indicated determinants of online shopping are: "the accessibility of products and services which are not available in traditional stores", as well as "saving time and a possibility of shopping around the clock". "An opportunity of comparing prices and the simplicity of finding interesting products" is moderately significant, while the least significant is "a possibility of using mobile coupons and a smaller effort involved in finding a given product" (Stefańska et al., 2017).

Since we assume, the intensity of using the Internet and mobile applications is correlated with the perceived motives and benefits it offers, we formulated following hypotheses:

$\mathrm{Hl}$ : the intensity of online shopping orientation is correlated with perceived motives of using mobile applications

$\mathrm{H} 2$ : the intensity of online shopping orientation is correlated with perceived benefits of using mobile applications 
In case of the online shopping involvement reflects the level of participation of customers in using web sides to do shopping. The level of involvement may depend from many variables, for example: previous experience with online or offline shopping, access to the Internet, time, money, stage of life cycle or any other variables. The intensity of usage the Internet is much higher among younger generations, especially Millennials and next one- Z-generation (Bilińska-Reformat et al., 2017). Their representatives spend much more time online than previous ones and they are more experienced with the Internet and mobile devices and applications (Stefańska et al., 2017).

There are two basic streams in mobile commerce primary or experimental research. The first stream is oriented towards technological aspect of mobile commerce (for instance: Lembke, 2002; Lee et al., 2007; Chong, 2013). The second stream tries to explore behavioural aspects of mobile commerce in various consumer groups and in various countries (for instance: Chan et al., 2013, Hamka et al., 2014; Kucharska, 2015; Molina-Castillo et al., 2008). However, in both streams, we observed the scarcity of comparative studies of various aspects of mobile commerce across countries and especially scarce are comparative analysis in postcommunist markets. Based on the theoretical analysis and research gaps, we formulated additional hypothesis:

H3: There are differences among countries as far as online purchase orientation is concern.

\section{Research methodology}

In this research the survey was taken on student population who represent the generation of Millennials. A paper and an online questionnaire were formed and it included 26 questions of different types: 17 one choice questions; 1 multiple choice, 8 Likert scale ranking questions. Questions were divided into several groups: (a) Socio-demographic characteristics; (b) Experience in online purchasing (questions were adapted according to Ling et al., 2010); (c) Smartphone and mobile application usage (questions were adapted according adapted according to Laundon et al., 2007; Knezevic et al., 2015); (d) Impulsive vs. planned purchasing (questions were adapted according to Ling et al., 2010); (e) Motivation and issues in mobile purchasing (questions were adapted according to Turban et al.; 2012, Chan et al., 2013; Knezevic et al.; 2015; Forsythe et al., 2006); (f) Usability and effectiveness of mobile purchasing (questions were adapted according to Thakur et al., 2013; Yadav et al., 2016).

However, in this paper we will focus only on question referring to experience in online purchasing and motivation and perceived which we will apply the basic descriptive statistics and advanced methods in order to compare results among countries: Poland, Croatia and Serbia. The gathered poll consisted of 454 answered and validated questionnaires. The structure of the sample according to demographic and economic criteria is shown in Table 2. 
Table 2

Characteristics of the Sample

\begin{tabular}{|c|c|c|c|c|}
\hline \multicolumn{5}{|l|}{ Country of origin } \\
\hline & Poland & Croatia & Serbia & Total \\
\hline $\begin{array}{l}\text { Number of } \\
\text { respondents }\end{array}$ & 157 & 163 & 134 & 454 \\
\hline Frequency in \% & 34,6 & 35,9 & 29,5 & 100 \\
\hline \multicolumn{5}{|l|}{ Frequencies in \% } \\
\hline Gender & Poland & Croatia & Serbia & Total \\
\hline Males & 39,5 & 28,8 & 27,6 & 32,2 \\
\hline Females & 60,5 & 71,2 & 72,4 & 67,8 \\
\hline Total & 100 & 100 & 100 & 100 \\
\hline \multicolumn{5}{|l|}{ Frequencies in \% } \\
\hline Age & Poland & Croatia & Serbia & Total \\
\hline less than 20 & 8,3 & 0,6 & 11,2 & 6,4 \\
\hline $20-25$ & 89,8 & 74,9 & 82,1 & 82,2 \\
\hline more than 25 & 1,9 & 24,5 & 6,7 & 11,4 \\
\hline Total & 100 & 100 & 100 & 100 \\
\hline
\end{tabular}

Source: Authors' work

\section{Results of analysis and discussion of results}

By using 7 grade Likert scale we examined attitudes of respondents towards motives and benefits of m-commerce. Following motives were examined: (1) Comparing prices and product information; (2) Shopping abroad without traveling costs; (3) Simplicity of finding interesting products/services; (4) Saving time; (5) Shop 24/7; (6) Availability of products/services which are not available at traditional stores; (7) Simplicity and less affordable process of purchasing than via mobile web browsers; (8) Checking product availability in the traditional store via mobile applications; (9) Checking product reviews via mobile applications; (10) Apps providing wide range of information help me to make better purchase decision (i.e. product details \& promotion); (11) Lack of pressure from salesperson; (12) Favourable offers; (13) Ability to locate physical stores via app; and (14) Using mobile coupons for discounts when shopping in the traditional stores. We examined following statements regarding benefits of m-commerce: (1) In general, I believe the use of Apps channel for purchasing products is useful to me; (2) Finding working hours of traditional stores via mobile applications; (3) Apps providing real-time and updated information help me to make better purchase decision; (4) Apps making products recommendation based on my browsing / shopping history is useful to me; (5) I prefer advance availability or exclusiveness of products in Apps; (6) The Apps channel is more convenient for shopping than other channels (e.g. Internet, physical store); (7) Using Apps for purchasing products enable me to finish my task of shopping efficiently.

In the next step, we verified, if there are any differences in the future online purchase orientation among countries. We assume, that the fact that respondents belong to the same generation, the country of origin do not influence on the online purchase orientation. Countries Croatia, Poland and Serbia belong to the group of CEE and if we compare Internet penetration, smartphone usage as well as historical heritage. In all three analysed countries the customers are very experienced and heavily smartphone-oriented users. The results are presented in Table 3. 
Table 3

Online Purchase Orientation

\begin{tabular}{|c|c|c|c|c|c|c|c|c|c|c|c|}
\hline & & Croatia & & & Serbia & & & Poland & & & \\
\hline & Mean & N & $\begin{array}{l}\text { Stand. } \\
\text { dev }\end{array}$ & Mean & $\mathrm{N}$ & $\begin{array}{c}\text { Stand. } \\
\text { dev }\end{array}$ & Mean & $\mathrm{N}$ & $\begin{array}{c}\text { Stand. } \\
\text { dev }\end{array}$ & $F$ & $p$ \\
\hline $\begin{array}{l}\text { It is likely } \\
\text { that I will } \\
\text { transact } \\
\text { with the } \\
\text { web } \\
\text { retailer in } \\
\text { the bear } \\
\text { future }\end{array}$ & 4,67 & 160 & 1,82 & 4,30 & 128 & 2,02 & 4,01 & 157 & 1,44 & 5,648 & ,004 \\
\hline $\begin{array}{l}\text { Given a } \\
\text { chance, I } \\
\text { intend to } \\
\text { use the } \\
\text { traditional } \\
\text { retailer's } \\
\text { web sites. }\end{array}$ & 4,39 & 160 & 1,97 & 3,83 & 128 & 2,02 & 4,46 & 157 & 1,29 & 5,177 & ,006 \\
\hline $\begin{array}{l}\text { Given a } \\
\text { chance, I } \\
\text { predict } \\
\text { that I } \\
\text { should } \\
\text { use this } \\
\text { retailer's } \\
\text { web sites } \\
\text { in the } \\
\text { future. }\end{array}$ & 4,65 & 160 & 1,87 & 4,13 & 128 & 1,97 & 4,12 & 157 & 1,22 & 4,910 & ,008 \\
\hline
\end{tabular}

The differences between countries are statistically significant, which means respondents from those countries differ in declarations for future online shopping $(p<0,05)$, therefore we accept $\mathrm{H} 3$. The online purchase orientation is the strongest among Croatian smartphone shoppers, while the least strong among Serbian. This correlates with level of development of these two countries. However, it is stronger in Croatian than in Poland although Poland has higher GDP per capita. However, the influence of factors connected with Internet penetration, orientation toward social networks and smartphone usage are stronger and it put Croatia at the first place.

In addition, we analysed if there is a correlation between shopping orientation and motives and benefits of using mobile applications. Results are presented in Table 4. 


\section{Table 4}

Correlation between Online Shopping Orientation and Motives and Benefits of Using Mobile Applications

\begin{tabular}{lccl}
\hline & $\begin{array}{l}\text { online shopping } \\
\text { orientation }\end{array}$ & $\begin{array}{l}\text { motives of using } \\
\text { mobile } \\
\text { applications }\end{array}$ & $\begin{array}{l}\text { benefits of using } \\
\text { mobile } \\
\text { applications }\end{array}$ \\
\hline $\begin{array}{l}\text { online shopping } \\
\text { orientation }\end{array}$ & 1 & & \\
$\begin{array}{l}\text { motives of using } \\
\text { mobile applications }\end{array}$ & $0,496^{* *}$ & 1 & 1 \\
$\begin{array}{l}\text { benefits of using } \\
\text { mobile applications }\end{array}$ & $0,447^{* *}$ & $0,674^{* *}$ & \\
\hline
\end{tabular}

Note: ${ }^{* *}$. Correlation statistically significant at $p<0.01$

Source: Authors' work

Correlation between variables is statistically significant therefore we confirm the first two hypothesis: $\mathrm{Hl}$ : the intensity of online shopping orientation is correlated with perceived motives of using mobile applications and $\mathrm{H} 2$ : the intensity of online shopping orientation is correlated with perceived benefits of using mobile applications.

\section{Conclusions}

In this paper we confirmed that the intensity of online shopping orientation is correlated with perceived motives and benefits of using mobile applications. This shows that mobile application are important factor in online shopping orientation of smartphone users. Therefore, creators of marketing and sales strategies of online and omnichannel companies should takes this into consideration. The second conclusion is that there are significant differences among online purchase orientation of smartphone shoppers by countries. Although observed countries have significant similarities, their differences are stronger and therefore they require specific approach concerning online retailing. Launching e-retail business which targets smartphone shoppers would require different strategical approach for each country. Therefore, localization of the strategy is important in online retailing as well. However, the level of the strategy differentiation and its directions would require additional research and this is interesting topic for future research.

There are certain research limitations. The first limitation is the age of the respondents. It would be interesting to conduct this type of research among different age groups. In addition, this research do not cover different product categories. It would be interesting to analyses shopping intentions of smartphone shoppers toward different product categories in order to get significant inputs for category management strategy. Additional limitation is that research does not include countries which significantly differ at both level of development according. GDP per capita and according the level of Internet penetration and general ecommerce development.

\section{References}

1. Bilińska-Reformat K., Wolny R. (2017), "Efekt ROPO w procesie zakupu przez młodych konsumentów na rynkach detalicznych" (ROPO Effect in Young Customers' Purchasing Processes on Retail Markets), in Patora, R., Kolasińska-Morawska, K. (Eds.), 
Agile Commerce - świat technologii i integracji procesowej (Agile Commerce the world of technology and process integration), Przedsiębiorczość i Zarzadzanie, Wydawnictwo Społecznej Akademii Nauk, Łódź-Warszawa, Vol. 4, No. 1, pp. 181-194.

2. Brockett, P. L., Golden, L. L., Song, A. (2012), "Managing risk in mobile commerce", International Journal of Electronic Business, Vol. 10, No. 2, pp. 167-184.

3. Cha, J. (2011), "Exploring The Internet As A Unique Shopping Channel To Sell Both Real And Virtual Items: A Comparison Of Factors Affecting Purchase Intention And Consumer Characteristics", Journal of Electronic Commerce Research, Vol. 12, No. 2 , 2011, pp. 115-132.

4. Chaffey, D. (2007), E-Business and E-Commerce, Prentice Hall, New Jersey.

5. Chan, F. T. S., Chong, A. Y. L. (2013), "Analysis of the determinants of consumers' mcommerce usage activities", Online Information Review, Vol. 37, No.3, pp. 443-461.

6. Cheung, M. Y., Luo, C., Sia, C. L., Chen, H. (2009), "Credibility of electronic word-ofmouth: Informational and normative determinants of on-line consumer recommendations", International journal of electronic commerce, Vol. 13, No. 4, pp9-38.

7. Childers, T. L., Carr, C. L., Peck, J., Carson, S. (2001), "Hedonic and Utilitarian motivations for online retail shopping behavior", Journal of Retailing, Vol. 77, No. 4, pp. 511-535.

8. Chong, A. Y. L. (2013), "A two-staged SEM-neural network approach for understanding and predicting the determinants of m-commerce adoption", Expert Systems with Applications, Vol. 40, No.4, pp. 1240-1247.

9. Durbhakula, V. K. , Kim, D. J. , (2011), "E-business for Nations: A Study of National Level Ebusiness Adoption Factors Using Country, Characteristics-Business-TechnologyGovernment Framework", Journal of Theoretical and Applied Electronic Commerce Research, Vol. 6, No. 3, pp. 1-12.

10. Eurostat (2017a), available at: http://ec.europa.eu/eurostat/statisticsexplained/index.php/Digital_economy_and_society_statistics_households_and_individuals (24 April 2017)

11. Eurostat (2017b), available at: http://ec.europa.eu/eurostat/statisticsexplained/index.php/E-commerce_statistics (23 April 2017).

12. Forsythe S., Liu C., Shannon D., Gardner, L. C. (2006), "Development of a scale to measure the perceived benefits and risks of online shopping", Journal of Interactive Marketing, Vol. 20, No 2, pp. 55-75.

13. Gehrt, K.C., Onzo, N., Fujita, K., Rajan, N.R. (2007), "The emergence of internet shopping in Japan: identification of shopping orientation-defined segment", Journal of Marketing Theory and Practice, Vol. 15, No. 2, pp. 167-177.

14. Hamka, F., Bouvman H., de Reuvera, M., Kroesena, M., (2014), "Mobile customer segmentation based on smartphone measurement", Telematics and Informatics, Vol. 31, No. 2, pp. 220-227.

15. Hennig-Thurau, T., Walsh, G., Walsh, G. (2003), "Electronic word-of-mouth: Motives for and consequences of reading customer articulations on the Internet", International journal of electronic commerce, Vol. 8, No. 2, pp. 51-74.

16. Internet World Statistics (2017), available at: http://www.internetworldstats.com/stats9.htm (27 September 2017)

17. Kabir, G., Akhtar Hasin, A. (2011), "Evaluation of customer oriented success factors in mobile commerce using fuzzy AHP", Journal of Industrial Engineering and Management, Vol. 4, No. 2, pp. 361-386.

18. Kim, J. B. (2012), "An empirical study on consumer first purchase intention in online shopping: integrating initial trust and TAM", Electronic Commerce Research, Vol. 12, No. 2, pp. 125-150.

19. Knezevic, B., Delic, M., Knego, N. (2015), "Smartphones And Mobile Applications As Shopping Tools - Attitudes of Young Retail Consumers In Croatia", in Pintilescu, C., Wierzbiński, B., Zarotiadis, G. (Eds.) Proceedings of the 11 th International Conference of ASECU, "Openness, Innovation, Efficiency And Democratization As Preconditions For Economic Development", Cracow University of Economics, Kraków, pp. 339-353. 
20. Knezevic, B., Stefańska, M., Stojkovic, D. (2017), "General overview of usage of smertphones and mobile applications by young consumers in Poland, Croatia and Serbia", Przedsiębioczość Międzynarodowa / International Entrepreneurship, Vol. 3, No. 1, pp. 211-227.

21. Kucharska, B., (2015), "Wirtualizacja zachowań nabywczych jako przejaw innowacyjności konsumentów w handlu detalicznym" (Virtualization of shopping behavior as a form of innovations in retail sector), Marketing i Rynek, No 10, pp. 40-45.

22. Laundon, K. C., Traver, C. G. (2007), E-commerce, Prentice Hall, New Jersey.

23. Lee, C. C., Cheng, H. K., Cheng, H. H. (2007), "An empirical study of mobile commerce in insurance industry: Task-technology fit and individual differences", Decision Support Systems, Vol. 43, No.1, pp. 95-110.

24. Lee, M. K., Turban, E. (2001), "A trust model for consumer internet shopping, International journal of electronic commerce", Vol. 6, No. 1, 75-91.

25. Lembke, J. (2002), "Mobile commerce and the creation of a marketplace", Info, Vol. 4, No.3, pp. 50-56.

26. Ling, K. C., Chai, L. T., Piew, T. H. (2010), "The Effects of Shopping Orientations, Online Trust and Prior Online Purchase Experience toward Customers' Online Purchase Intention", International Business Research, Vol. 3, No. 3, pp. 63-76.

27. McKnight, D. H., (2001), "What trust means in e-commerce customer relationships: An interdisciplinary conceptual typology", International journal of electronic commerce, Vol. 6, No. 2, pp. 35-59.

28. Molina-Castillo, F. J., López-Nicolas, C., Bouvman, H. (2008), "Explaining mobile commerce services adoption by different type of customers", Journal of Systemics, Cybernetics and Informatics, Vol. 6, No. 6, pp. 73-79.

29. Pavlou, P. A. (2003), "Consumer acceptance of electronic commerce: Integrating trust and risk with the technology acceptance model", International journal of electronic commerce, Vol. 7, No. 3, pp. 101-134.

30. Rohm, A. J., Swaminathanb, V. (2004), "A typology of online shoppers based on shopping motivations", Journal of Business Research, Vol. 57, No. 7, pp. 748-757.

31. Sarkar, A. (2011), "Impact of Utilitarian and Hedonic Shopping Values on Individual's Perceived Benefits and Risks in Online Shopping", International Management Review, Vol. 7, No. 1, pp. 58-65.

32. Statista (2016), available at https://www.statista.com/statistics/347221 (accessed 26 September 2016).

33. Stefańska, M., Bilińska-Reformat, K. (2017). "Czy atrakcyjna cena zastapi brak kontaktu fizycznego w przypadku zakupów online? Przykład smart shoppers" (Will Attractive Price Replace the Lack of Physical Contact When Shopping Online? The Example of Smart Shoppers), in Patora, R., Kolasińska-Morawska, K. (Eds.), Agile Commerce - świat technologii i integracji procesowej (Agile Commerce - the world of technology and process integration), Przedsiębiorczość i Zarzadzanie (Entrepreneurship and Management), Wydawnictwo Społecznej Akademii Nauk, Łódź-Warszawa, Vol. 4, No. 1, pp. 227-239.

34. Stefańska, M., Wanat, T. (2017), "Benefits from using mobile applications by Millennials - a gender and economic status comparative analysis", in Andreani, J. C. (Ed.), The Proceedings of XVI International Marketing Trends Conference, Madrid, Paris-Venice Marketing Trends Association, available at: www.marketing-trends-congress.com/papers

35. Suh, B., Han, I. (2003), "The impact of customer trust and perception of security control on the acceptance of electronic commerce", International journal of electronic commerce, Vol. 7, No. 3, pp. 135-161.

36. Thakur, R., Srivastava, M. (2013), "Customer usage intention of mobile commerce in India: an empirical study", Journal of Indian Business Research, Vol. 5, No. 1, pp. 52-72.

37. Turban, E., King, D., Lee, J., Liang, T. P., Turban, D. (2012), Electronic Commerce 2012: A Managerial and Social Networks Perspective, Pearson, New York \& London.

38. Turban, E., King, D., Lee, J., Liang, T. P., Turban, D. (2015), Electronic Commerce: A Managerial and Social Networks Perspective, Springer, Berlin. 
39. Venkatesh, V., Morris, M. G., Davis, G. B., Davis, F. D. (2003), "User acceptance of information technology: Toward a unified view", MIS Quarterly, Vol. 27, No. 3, pp. 425478.

40. Yadav, R., Sharma, S. K., Tarhini, A. (2016), "A multi-analytical approach to understand and predict the mobile commerce adoption", Journal of Enterprise Information Management, Vol. 29, No. 2, pp. 222-237.

41. Yuan, S. T., Cheng, C. (2004), "Ontology-based personalized couple clustering for heterogeneous product recommendation in mobile marketing", Expert Systems with Applications, Vol. 26, No. 4, pp. 461-476.

42. Zhang, L., Zhu, J., Liu, Q. (2012), "A meta-analysis of mobile commerce adoption and the moderating effect of culture", Computers in Human Behavior, Vol. 28, No. 5, pp. 1902-1911.

\section{About the authors}

Magdalena Stefańska, Ph.D. is an associate professor of Poznan University of Economics and Business, Faculty of Management. Her research interests are: retail, corporate social responsibility, modern retail formats and electronic commerce. She has published numerous scientific papers and books. She is a regular reviewer and a member of the editorial board at several scientific journals in field of general economics, business administration, management and marketing. The author can be contacted at magdalena.stefanska@ue.poznan.pl.

Blazenka Knezevic, Ph.D. is an Associate professor at Faculty of Economics and Business, University of Zagreb, Croatia. She teaches courses: Retail information systems; Economics of electronic commerce; Trade and trade policy; Procurement management; Supplier relationship management. She participated in various scientific research projects and published more than 40 papers in conference proceedings, books and academic journals. She is a member of the editorial board of the Business Excellence Journal (BEJ) and advisory board of Entrepreneurial Business and Economics Review (EBER). She is the regular reviewer at several international scientific journals. The author can be contacted at bknezevic@efzg.hr.

Dragan Stojkovic, Ph.D. is an associate professor of University of Belgrade Faculty of Economics. He received MBA (marketing major) from Hofstra University. He received Ph.D. from University of Belgrade Faculty of Economics in the field of e-commerce and multichannel retailing. His research fields are multichannel retailing, retail marketing and management. Courses taught: Trade Marketing and Sales Management, Trade Management, Marketing Channels, E-commerce, Marketing Channels Strategies, Internet Marketing. He has published papers in numerous international and Serbian publications. He participated in over 100 consulting projects for Serbian and foreign companies, Government of Serbia, and international organizations. The author can be contacted at dstojkovic@ekof.bg.ac.rs. 